\title{
A COMPARATIVE STUDY OF STIMAN'S RULE IN JA'FARI JURISPRUDENCE AND CIVIL LAW
}

\author{
Mohammad Ali Raghebi ${ }^{1}$ \\ Rezvan Najarian Darz ${ }^{2}$
}

\begin{abstract}
Stiman is one of the most important Fiqh rules by virtue of which, each individual by any reason becomes a trustee for property of another person will not be responsible for the loss of that property unless he has committed a mistake (whether extremes of excess and deficiency). The essence of Stiman's rule has been considered as the truth of title of an owner's deposit which in fact another one's being trustee is dependent on the property owner's permission and the religious deposit in which a person by the order of the religious order (or the legislator) becomes trustee. The Islamic Jurisprudence and civil law towards Stiman's rule in each of the contracts such as power of attorney, deposit, loan, renting, mortgage, bailment of a capital, and attending the ownership deposits which deposit description is the main base of these contracts and in religious
\end{abstract} deposits such as missed property and custody in which a profile of deposit description is observed, is in this way that the trustee in every above contracts shall not be regarded as guaranteed in case of the property loss and the owner or law has no right for seeking him the loss compensation and only in a way they can resort to him that the trustee has made extremes of excess and deficiency in it.

Keywords: Stiman, trustee, pledge, excess and deficiency

\section{Introduction:}

In Iranian Fiqh and civil law of which some of the content is an imitation of European rules especially French civil law and to some extent Switzerland and among the Fiqh principles we encounter

\footnotetext{
${ }^{1}$ Faculty Member of Qom University, -Iran, Faculty of Theology and Islamic Studies in the field of theology and Islamic sciences with the tendency of jurisprudence and the basics of Islamic law with the academic rank of professor.

2 Ph.D. student of Qom University-Iran, Department of theology and Islamic Encyclopedia, Islamic jurisprudence and law.
} 
Stiman's rule or trustee's not being guaranteed. This principle has use in all of areas of transaction Fiqh and civil law. Few scholars and lawyers has individually investigated adapting cases of this principle and most scholars mentioned it for the sake of the discussion subject or for the reasons they launch for their question. For example, the scholars in the book LEASE AND DEPOSIT IN REASONING they refer to Stiman principle for tenant's not being guaranteed and they say as these people are regarded as trustee are not guarantee for loss so the property owner has no right to resort to them.

The concise content of this principle is in this way that whenever somebody is allowed by the governor to intervene into a property for maintaining it or for using its benefits, if that property gets wasted without any excess and deficiency by the allowed person he shall not be guaranteed.

In this writing in the first part after defining Stiman principle we explain the two words of ownership and religious deposits and in the second part we proceed to a comparative study of Stiman principle and along with Fiqh study of the principle we will refer to cases of civil law which in fact the Fiqh documentary of that cases and approving it are based on this principle.

\section{Stiman principle definition}

One of Fiqh principles that is related to some part of Fiqh orders and legal issues is Stiman principle or Non guarantee principle of trustee, based on which automatic guarantee stemming from property withdrawal is removed and it is said that the trustee is not guaranteed. For example as the tenant in rental contract, attorney in power of attorney contract, borrower in borrowing contract and $\ldots$ are named trustee whereas they have no fault towards damaging or wasting the property which is delivered to them from the opposite side are not blamable, they are not considered as guaranteed. This principle means if a person has another one's property as deposit and that property gets wasted by the trustee without any excess and deficiency, the trustee shall not be guaranteed against that property and the order of liability of spoil of property shall not be pronounced against him, as in the Art. No. 614 GH. M, this text is mentioned:

"The trustee is not guaranteed for the waste or 
damage of the property deposited to him unless in case of excess and deficiency." (Imami, 168/2).

\section{Ownership and religious deposit}

Deposit is in two kinds: Ownership deposit and religious deposit (Legal). Ownership deposit which is regarded in Fiqh and legal texts as contractive deposit means that the owner takes his property with his option and contest to the other one so that he keeps it or possess it. In addition to deposit, in borrowing, bailment of a capital and rent we encounter ownership deposit (Taheri, 372/1). But religious (legal) deposit, is that kind of deposit which without owner's knowledge, a person on the strength of the order of religion or law is allowed to keep or possess another's property such as parents' dominance on child's or insane property, including the religious governor, inheritor, father, paternal grandparents, father's or paternal grandfather's trustee and also finder of another's property. That is so when with any reason a property with unknown owner is handed to somebody else. (Maraghei, 248/2).
In short, the person in this cases are religious and legal trustee, that is by the order of law or religion and in three directions of observing the owner's interest, trustee's interest, and the interests of both, he becomes trustee.

After investigating the concept of Stiman and explaining two above words, we adapt Stiman principle in each of the ownership and religious deposits in terms of Fiqh and legacy and study it.

\section{Adaptation cases of Stiman Principle in ownership deposits}

\section{Power of attorney}

Power of attorney which is one of the most famous and applicable contracts in Islam and nations is of the kinds of ownership deposits that by the client's permission the property is taken under the control of the attorney. The scholars assert about the client's not being guaranteed in case of the property loss under his control that the attorney is trustee and is not guaranteed toward whatever is in his hands and losses unless in case of excess and deficiency. (Fakhr Al-Mohaqeqin, 350/2; Mohaqeq Helli; 161/2). In the civil law there is not any stated Art. About the attorney's not being guaranteed but there is a saying 
about the attorney's fault intention in Art. 666 as:" when the client's suffers a loss because of the attorney's fault that is customarily considered as its cause is shall be responsible." It is understood well from this Art. That a faultless attorney that is with no excess and deficiency shall not be guaranteed. (Gholami, 77)

\section{Deposit}

Deposit is of the kind of ownership deposit because the owner with his will and through a contract he makes with another, delivers his property to another one on the intention of maintenance and therefor the owner choose the safe keeper as his agent. In Fiqh texts it is explicitly mentioned that the deposit receiver is not guaranteed. Mohaqeq Helli believes that deposit is a token which bears no commitment and guarantee for the deposit receiver unless he has made fault and violation in its loss. (Mohaqeq Helli, 150/1)

In civil law in various cases the trustee's not being guaranteed is noted drrectly and indirectly. Art. 614 of civil law says: "trustee is not guaranteed towards the property loss or waste that was deposited to him unless in case of excess or deficiency."

\section{Loan}

Loan is also of the kind of ownership token in which the owner hands his property freely over to the borrower for his use and as he is trustee so he is not guaranteed.

The subject of borrower's not being guaranteed is famous in Shia Fiqh so that this matter has been noted as a Fiqh principle in scholars' Fiqh principles books. (Shahid Aval, 272/2Bojnoordi, 9/7). Sheikh Toosi says in this case when in loaning its being allowed is proven, so loaning is token and it bears no guarantee unless the property owner stipulates that the borrower is guaranteed for the property waste. (Sheikh Toosi, Mabsoot 49/3)

In civil law also from several Articles, borrower's not being guaranteed is used that we refer to two examples; Art. 640: "the loan receiver is not guaranteed against the property waste or damage unless in case of excess or deficiency". Art. 640: "loan receiver, is not responsible for the damage stemming for borrowed property use 


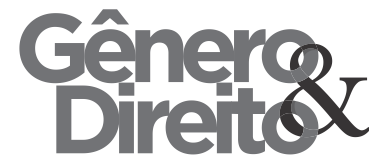

unless he used it in other case than the allowed one."

\section{Rent}

One other ownership token sample, is tenants possession which in regular form and without excess or deficiency is not guaranteed because in rent contract, the lessor allows the tenant to use the interests of what is rented and this allowance by the lessee indicates that rent is an ownership token. Ibn Hamzeh Toosi says about the tenants not being guaranteed in case of waste if rented case becomes wasted by the tenant without excess he shall not be its guaranteed. (Ibn Hamzeh Toosi, 367)

As per the Art. 631 of civil law the rented case in tenant's hand is token and on the order of $1^{\text {st }}$ part of Art. 490 he must act customarily in using the rented case and avoid from excess and deficiency. And also as per the Art. 498 "the tenant is not guaranteed against the rented case that is if the rented case gets wasted totally or partly he shall not be responsible but if the tenant makes excess or deficiency, he is guaranteed even if the damage is not due to the excess or deficiency (Taheri, 194/4).
Mortgage:

Another actual example of trust is mortgage contract, because the mortgagee has taken the mortgaged property with the permission of its owner and has kept it as security and trust. Late Imam Khomeini about the mortgagee that is not guarantor in favor of the party or any defect during the mortgage, says that the mortgaged property is a trust in the hands of the mortgagee and if it is lost or damaged without extremity, the mortgagee is not guarantor. (Mousavi Khomeini, 10/2)

As stated in Article 789 GH.M: "The mortgaged property in the possession of the mortgagee is considered as a trust and therefore the mortgagee is not responsible for its loss or damage, unless in case of fault."

Commendité: [Profit \& Loss Sharing]

It's a contract that a person gives a capital to another person to work with it and both of them share the profit and loss. So, one of the characteristics of Commendité is trust. Because in this contract, the performer is a partner that is permitted and the shared property is in his hands and one of the rules related to the partnership is that the property is a 
trust in the hands of the partner, because the possession of the shared property by each of the partners is based on the permission. Therefore, the common property in the hands of the partners is a trust. The first martyr in Lome says that the performer in Commendité is trustee and is not guarantor except in case of extremity. (The first martyr, 146)

Civil Law states in Article 556 that :"The performer has the force of trustee and is not the guarantor of Commendité property unless in case of extremity." Therefore, because the performer, as per the above article, has the force of trustee, Article 614 GH.M that says "The trustee is not the guarantor for the loss or damage of the property unless in case of extremity", also includes the performer.

\section{Partnership:}

An important point in partnership is that the shared (joint) property in the hands of the partners is a trust. Article 584 of Civil Law: "The partner that has the shared property in his hands, has the force of trustee and is not the guarantor for its loss or damage unless in case of extremity." (Taheri, $313 / 4)$
Also the person who was permitted by the partners for managing the shared property (Whether he is from among the partners or is an alien) has the force of an attorney and he should act within the scope of the power of attorney and the permission and as far as he is not beyond the scope of the permission, he is the trustee and is not the guarantor for any damage and is the guarantor in case of extremity. (Najafi Esfahani, 306 \& $308 / 26)$

Civil Law states in Article 556 that: "The partner that has been permitted to manage the shared property under the contract can do whatever is necessary for managing and will not be liable for any damages resulting from his actions unless in case of extremity." (Taheri, 313/4)

The cases of compliance of Estiman Rule in law trusts

\section{Lost Property:}

If a property is found by a person, he is called "Moltaqet" in Fiqh terms [Fiqh=Jurisprudence], and he should possess that lost property [loqate] and as per religious standards, he should find the original owner or use the property in the cases prescribed in the 
fiqh. Here, if the actions of the person are intended to protect the lost property [loqate] and determine the religious obligation of it, and there is no intention of betrayal and personal exploitation, the property is as a law trust in his hands, which, in the event of loss, he is not guarantor in a famous Fiqh opinion. (Savad Kouhi Far,55) Muhaqqiq al-Hilli says about lost property that: "The property is as a law trust in the hands of the finder for one year and he is not guarantor except in case of invasion or extremity. "(Muhaqqiq al-Hilli, 236/3)

Article 168 of Civil Law, following the famous opinion in Shia Fiqh, states that: "If the found property is laid waste without the fault of the finder, the finder is not guarantor."

\section{Guardianship and wardship:}

In general, special guardian (father, paternal grandfather and administrator) and general guardian (the ruler of the Shari'ah and the guardian appointed by ruler) have been considered as trustee following Imamieh Fiqh [ jurisprudence] percepts in Civil Law. Article 631 of Civil Law says: "If someone takes possession of another person's property under a title other than trustee, and the regulations of this law have placed him as a trustee in relation to that property, he is like a trustee. Therefore, tenant will not be guarantor for rented property, guardian or ward for property of nonage or of the person on whom was placed guardianship unless in case of extremity." Also guardian is a trustee in relation to properties of a ward and the general rule of trust is that, if there is no extremity, the trustee is not guarantor for loss and damage of those properties toward the owner, but if there is any extremity by the trustee, which means that the trustee has failed to perform the assignments assigned by law to him, he will be the guarantor of the loss or damage found in the area of this shortcoming." As stated in Article 1238 GH.M: "A guardian who fails to protect the property of someone who is under guardianship, is responsible for the loss or damage resulted from deficiency or waste, even if that deficiency or waste is not due to extremity of the guardian." (Taheri, 153/1)

\section{Conclusion:}

In this study, we first looked at the concept of Estiman, and in this case it was said that Estiman means that the 
trustee is not guarantor in the assumption of non-extremity, and we divided it into ownership trust and law trust. Ownership trust is a trust which depends on the owner's permission but law trust is a trust which does not depend on the owner's permission, but a person is appointed as trustee by lawmaker. In the next section, we examined the contracts which Estiman rule is matched, which are somehow based on trust and under this title we introduced contracts of power of attorney, mortgage, rent, deposit, loan, Commendité as ownership trusts and Guardianship and wardship as religious and law trusts and we concluded that in all of them, a person who has owned a property, is considered a trustee and is not guarantor even in case of trustee's extremity in relation to that property."

\section{References}

Ibn Hamzeh Toosi, M, (1987). Al-Vasila Ela Nil Al-fazilah. Qom-Iran, Ayatollah Marashi Najafi Publisher, 1st print.

Emami, SH. (2002). Civil Law. Tehran, Iran, Islamieh Publisher, 34th print.
Hosseini Maragheie, MA, (1996). AlAnavin AlFaqihe. Qom, Iran, Islamic Office dependent on Society of Seminary Teachers of Qom, 1st print.

Helli Fakhr Al-Mohaqeqin, MBY, (1967). Izah Al-Favahed. Qom, Iran, Ismailian Institute, 1 st print.

Savad Koohi Far, Sam. Laqteh. Thesis of Master's degree, Private Law, Faculty of law of Shahid Beheshti University. 1990.

Taheri, H. (1997). Civil Law. Qom, Iran, Islamic Office dependent on Society of Seminary Teachers of Qom, 2nd print. (2008). Princioles of Fiqh, Islamic Publishing Office dependent on Society of Seminary Teachers of Qom, 1 st print.

Ameli, the 1st martyr, M, Al-qavaed and Al-favaed, Qom, Iran, Mofid Bookshop, 1 st print.

(1990). Al-lome Aldameshqiah fi Fiqh Al-ememiah. Beirut, Lebanon, Dariaterath- Islamic Aldar, 1st print. 


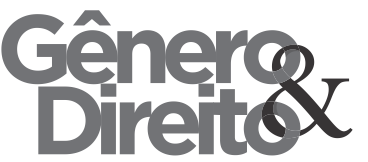

Periódico do Núcleo de Estudos e Pesquisas sobre Gênero e Direito

Centro de Ciências Jurídicas - Universidade Federal da Paraíba V. 8 - No 02 - Ano 2019 - Special Edition ISSN | 2179-7137 | http://periodicos.ufpb.br/ojs2/index.php/ged/index

Gholami, G, An Attorneys

Commitments, Thesis of Master's degree, Private Law, Faculty of law of Shahid Beheshti University. 2000.

Mohaqeq Helli, A, (1988), Shera AlIslamfi Masael Alhalal and Alharam, Qom-Iran, Ismailian Institute, 2nd print. (1997). Al-Mokhtasar Alkafe

Fi FIQH Al-emamieh, Qom, Iran, Almatbooat Aldinieh Institute, 6th print.

Sheikh Toosi, M, (1987) Al-Khalaf, Islamic Publishing Office dependent on Society of Seminary Teachers of Qom, 1 st print.

Mousavi Bojnordi, SM. (2009). AlQavaed Al-Fiqhiah. Qom-Iran, Our Reasons Publishings, 4th print.

Mousavi Khomeini, SR, (1945). Tahrir Al-Vasileh, Qom, Iran, Darolelm Press Institute, 1 st print.

Najafi Isfahani, S, (1984). Javaher AlKalam fi SHARH Sharae Islam, Beirut, Lebanon, Dar Ehya Altarath Alarabi, 7th print 